\title{
PENGEMBANGAN MULTIMEDIA INTERAKTIF PENGUKURAN TEKNIK UNTUK MENINGKATKAN HASIL BELAJAR SISWA SMK
}

\author{
Suyitno \\ Pendidikan Teknik Otomotif FKIP UMP \\ Email: yitnoback@yahoo.com
}

\begin{abstract}
The objectives of this study were: (1) to determine the process of the interactive media development for the course of Technical Measurement, and (2) to analyse the effectiveness of the media. This study is categorised into research and development. The data collection techniques used questionaires and tests. The results show: (1) the process of the interactive media development consisted of needs analysis, product development, individual test, small groups test and final product implementation. (2) The developed product is proved to be an effective instructional media to improve the students' achievement in the course of Technical Measurement. There is a positive and significant difference between the students treated with the developed interactive media and the students treated with the conventional media. It was supported by the mean scores of the experimental and control groups were 78.83 and 69.78 respectively.
\end{abstract}

Keywords: interactive, media, learning outcomes, learning process

\begin{abstract}
ABSTRAK
Penelitian ini bertujuan untuk mengetahui: (1) proses pengembangan media interaktif untuk pembelajaran pengukuran teknik; dan (2) efektivitas pengembangan media interaktif untuk pembelajaran pengukuran teknik. Penelitian ini merupakan research and development. Pengumpulan data dilakukan menggunakan angket dan tes. Hasil penelitian antara lain: (1) proses pembuatan media pembelajaran dilakukan melalui tiga tahap yaitu: analisis kebutuhan, pengembangan produk, uji coba satu-satu, uji coba kelompok kecil dan implementasi produk akhir; dan (2) produk multimedia ini dapat digunakan sebagai salah satu media untuk meningkatkan pemahaman materi pengukuran teknik. Terdapat perbedaan hasil belajar antara siswa yang menggunakan media interaktif dan siswa yang menggunakan media konvensional. Media interaktif lebih efektif daripada media konvensional, dapat dilihat dari rerata kelas eksperimen sebesar 78,83 yang lebih besar dari rerata kelas kontrol sebesar 69,78.
\end{abstract}

Kata kunci : hasil belajar, interaktif, media, pembelajaran

\section{PENDAHULUAN}

Pendidikan kejuruan adalah pendidikan yang mempelajari pelatihan secara spesifik yang dapat digunakan dalam dunia kerja (Pavlova, 2009: 7). Prosser dan Quekqly (1950: 2) memaparkan bahwa pendidikan kejuruan merupakan sebuah konsep pengalaman yang menyeluruh bagi setiap individu yang belajar untuk kesuksesan dunia kerja. Dalam hal ini, pendidikan kejuruan banyak belajar tentang persiapan-persiapan sebelum ke dunia kerja. Pembelajaran tersebut meliputi pembelajaran kognitif, afektif, dan psikomotorik. Pendidikan kejuruan adalah pendidikan yang berorientasi pada pengembangan proses dan hasil dari pembelajaran. Proses akan menempa peserta didik untuk dapt mencapai kompetensi yang diharapkan. Kualitas lulusan menjadi tolok ukur keberhasilan pendidikan kejuruan. Finch (1999: 14) menjelaskan bahwa the ultimate success of a vocational and technical curriculum is not measured merely through student educational achievement but through the result of that achievement-result that take the form of performance in the work world. Thus, the vocational and technical curriculum is oriented toward process (experience and activities 
within the school setting) and product (effect of these experiences and activities on former student).

Berdasarkan hasil survei pendahuluan di SMK Negeri 1 Girisubo diperoleh informasi hasil belajar siswa dalam perawatan sistem pengisian masih rendah. Siswa mengalami kesulitan dalam mengidentifikasi fungsi, letak komponen-komponen dan cara perawatan yang benar pada pemeliharaan sistem pengisian. Hal ini menyebabkan kurangnya motivasi siswa dalam mengikuti proses belajar mengajar di dalam kelas. Sebagian guru dalam pembelajaran masih menggunakan metode ceramah dan menulis pada papan tulis yang tidak melibatkan siswa secara aktif. Selain itu ketersediaan media pembelajaran masih terbatas dan belum ada pengembangan media pembelajaran yang sesuai, sehingga tujuan kompetensi dasar tidak dapat tercapai. Hal ini berdampak pada hasil belajar pemeliharaan sistem pengisian rata-rata masih rendah dengan kriteria ketuntasan minimal (KKM) yaitu indeks prestasi 2,67 belum dapat tercapai. Proses pembelajaran yang berlangsung di SMK N 1 Girisubo pada materi Pengukuran Teknik khususnya, masih menggunakan media tayang satu arah seperti Power Point.

Guru masih menggunakan metode ceramah untuk menyampaikan materi pelajaran di depan kelas, siswa mendengarkan dan mencatat, sehingga pada saat siswa mendapat kesempatan untuk bertanya, kebanyakan siswa tidak mengambil kesempatan itu, hal tersebut kemungkinan disebabkan karena siswa tidak mengetahui apa yang akan ditanyakan, sebab materi yang diberikan tidak dipahami. Metode seperti ini kenyataannya belum efisien dalam pelaksanaan belajar mengajar. Penggunaan media pembelajaran pada mata pelajaran Pengukuran Teknik di Jurusan Teknik Otomotif Paket Keahlian Teknik Kendaraan Ringan sangat terasa urgensinya karena sebagian besar materi pembelajaran yang diselenggarakan adalah suatu proses atau tahapan yang memerlukan adanya visualisasi. Sebagai upaya dalam meningkatkan kualitas pembelajaran khususnya pada materi Pengukuran Teknik diperlukan penggunaan media pembelajaran yang menarik pada semua topik kuliah baik teori maupun praktik. Hal ini dimaksudkan untuk memberikan visualisasi dan transfer materi dengan mudah dari pengajar kepada siswa. Materi Pengukuran Teknik terdiri dari teori dan praktisi. Materi tersebut tergabung menjadi satu dan saling mendukung. Proses pembelajaran materi Pengukuran Teknik dilaksanakan secara terpisah antara teori dan praktik. Umumnya, teori diberikan guru dengan metode ceramah secara garis besar saja, kemudian siswa diberi job praktik. Cara demikian di pandang kurang efektif karena tidak semua siswa menyukai cara belajar tersebut.

Pembelajaran materi Pengukuran Teknik layaknya menggunakan banyak media, karena kemampuan psikomotor dan kognitif siswa lebih diutamakan. Perkuliahan yang secara dominan menggunakan metode ceramah dan praktik dapat menyebabkan siswa kurang mendapat pengalaman belajar. Untuk mengatasi hal tersebut diperlukan media pembelajaran yang dapat mengakomodasi banyak cara belajar siswa dan memberi pengalaman belajar yang lebih. Media pembelajaran Interaktif yang berwujud text, visual, dan simulasi dapat membantu siswa mendapat pengetahuan lebih, pemahaman konsep yang lebih mendalam, serta mengetahui aplikasi ilmu yang dipelajari. Media pembelajaran interaktif yang bersifat dinamis sangat mendukung jika digunakan dalam proses pembelajaran, karena media pembelajaran interaktif mampu menjelaskan materi yang mempunyai daya abstraksi tinggi dan rumit. Media Pembelajaran interaktif dapat dikemas sedemikian rupa sehingga dapat membuat siswa mau mempelajari sendiri materi yang disediakan dalam media tersebut. Media pembelajaran interaktif dapat diisi banyak sekali materi teori, praktik, maupun benda asli dalam bentuk text maupun visual yang dapat memberikan pengalaman langsung kepada siswa. Penggunaan media pembelajaran interaktif diharapkan mampu mengurangi 
hambatan yang sering dialami guru maupun siswa dalam proses belajar mengajar di kelas dan pembelajaran mandiri. Oleh karena itu penulis meneliti tentang pengembangan media interaktif Pengukuran Teknik di SMKN 1 Girisubo Gunung kidul.

\section{METODE}

Penelitian ini menggunakan desain penelitian dan pengembangan atau research and development karena metode penelitian yang digunakan untuk menghasilkan produk tertentu. dan menguji keefektifan produk tersebut. Tempat penelitian adalah di SMK Negeri 1 Girisubo. Terdapat 5 langkah utama dalam prosedur penelitian dan pengembangan ini. langkah prosedur pengembangan tersebut dapat dilustrasikan pada Gambar 1.

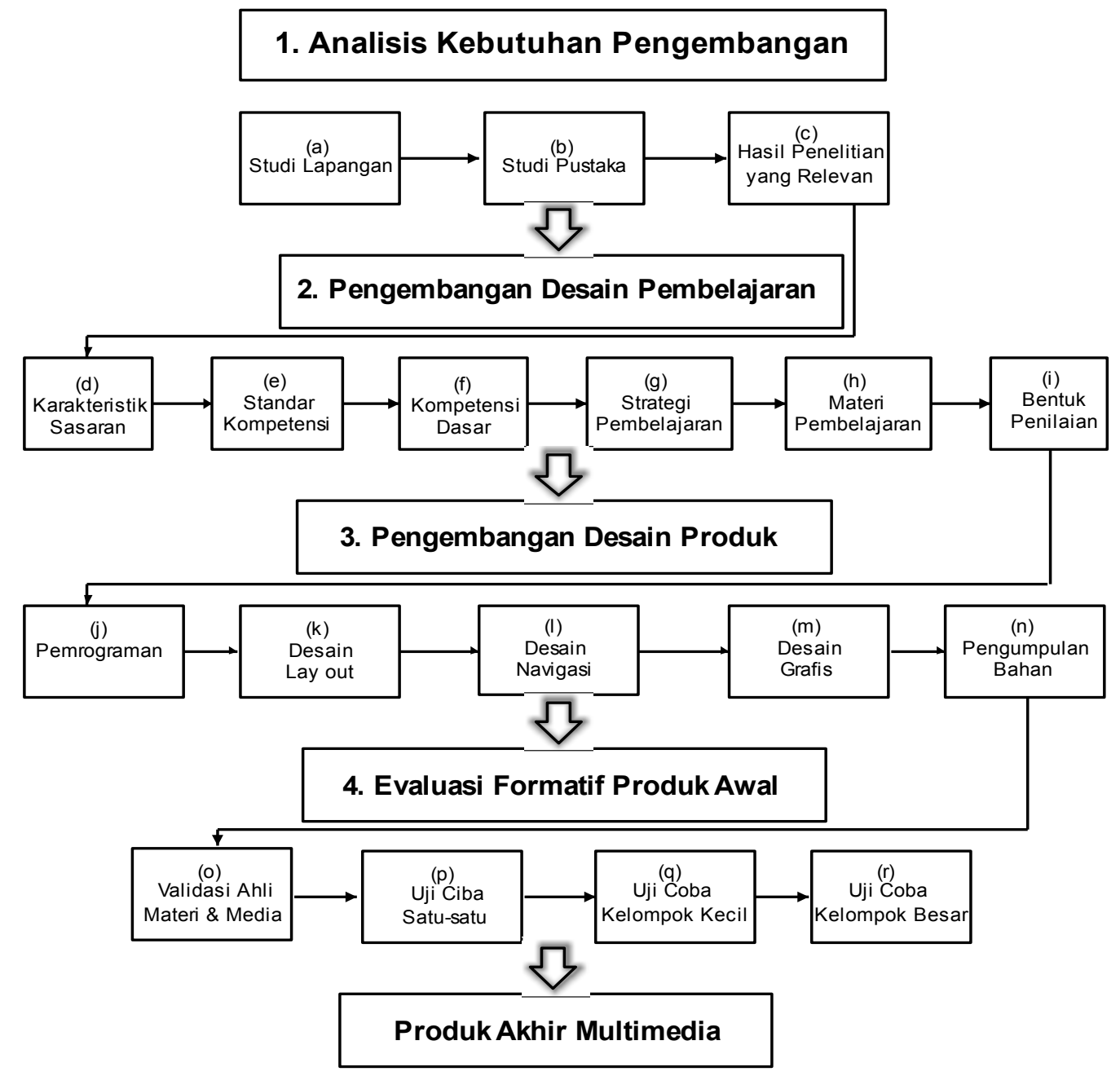

5. Implementasi \& evaluasi Sumatif

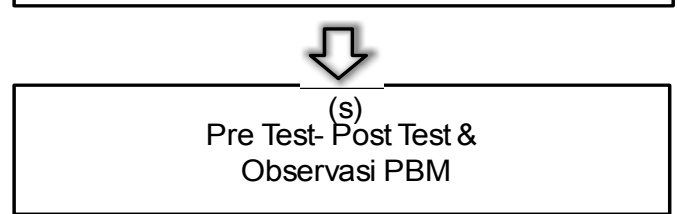

Gambar 1. Prosedur Pengembangan Modifikasi dari Dick and Carrey (2001) dan Borg and Gall (1989) 
Gambar 1 menjelaskan tentang langkah prosedur penelitian pengembangan ini yaitu; (1) analisis tentang kebutuhan pengembangan, (2) desain pembelajaran, (3) pengembangan desain produk, (4) evaluasi produk awal, dan (5) implementasi dan evaluasi sumatif.
Tahapan uji coba yang dilakukan dalam penelitian ini dilaksanakan setelah dilakukan validasi oleh ahli materi dan ahli media. Desain uji coba tersebut dijelaskan pada Gambar 2.

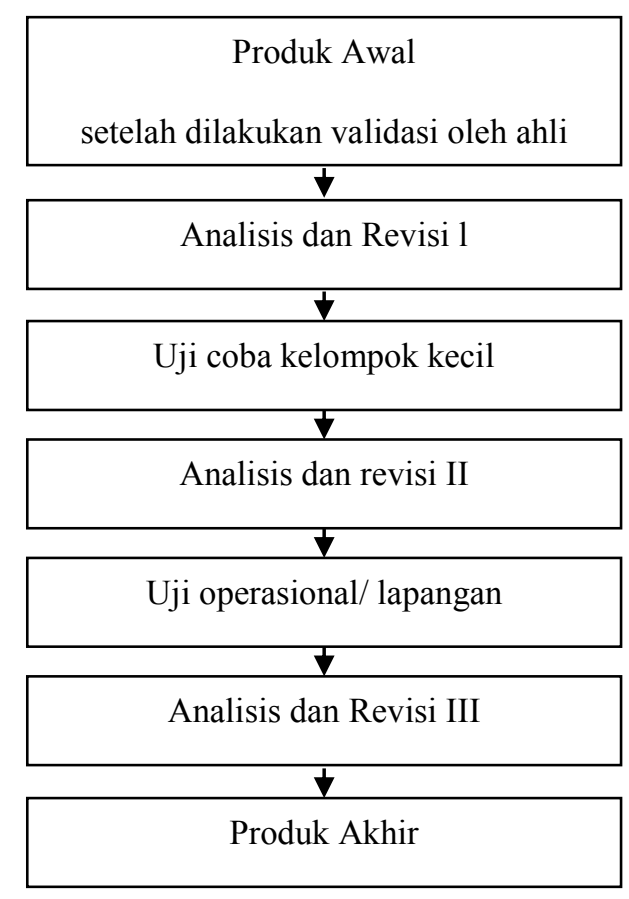

Gambar 2. Desain Uji Coba Produk

Populasi dalam penelitian ini adalah siswa kelas XI paket keahlian Teknik Kendaraan Ringan sebanyak 60 siswa yang terbagi atas 2 kelas dengan jumlah siswa masing-masing kelas 30 siswa. Pada penelitian ini kelas XI TKR A sebagai kelas eksperimen dan kelas XI TKR B sebagai kelas kontrol. Analisis efektif media dengan melihat rata-rata hasil belajar siswa.

\section{HASIL DAN PEMBAHASAN}

Data yang diperoleh dalam penelitian ini dianalisis kembali berdasarkan masing-masing komponen dalam setiap angket dan lembar observasi yang diberikan. Analisis dilakukan untuk mengetahui sejauh mana multimedia yang dikembangkan itu dapat digunakan, serta bagian-bagian yang masih perlu direvisi agar multimedia yang dikembangkan benar-benar dapat digunakan untuk pencapaian efektivitas pembelajaran. Berdasarkan hasil pengolahan data kriteria yang telah ditentukan, diketahui bahwa media pembelajaran pengukuran teknik yang dikembangkan termasuk dalam kriteria valid dan media tersebut dapat digunakan dalam proses pembelajaran. Berdasarkan hasil validasi ahli materi dapat dianalisis sebagai berikut: (1) kesesuaian materi untuk ditampilkan dalam bentuk animasi, ahli materi menjawab "a" sesuai, sehingga skor yang diperoleh 4 dengan persentase sebesar $100 \%$.

Berdasarkan kriteria interpretasi data $100 \%$ termasuk kualifikasi valid, karena media animasi yang telah dikembangkan memiliki kesesuaian materi untuk ditampilkan dalam 
bentuk animasi; (2) kesesuaian media dengan tujuan materi, ahli materi menjawab "a" sesuai, sehingga skor yang diperoleh 4 dengan persentase sebesar $100 \%$.

Berdasarkan kriteria interpretasi data $100 \%$ termasuk kualifikasi cukup valid, karena media animasi ini cukup sesuai dengan materi yang dipilih; (3) kemudahan siswa dalam mendalami materi dengan menggunakan media animasi, ahli materi menjawab "b" cukup mudah, sehingga skor yang diperoleh 3 dengan persentase sebesar $75 \%$.

Berdasarkan kriteria interpretasi data $100 \%$ termasuk kualifikasi valid, karena narasi dalam media animasi sesuai dengan gambar yang ditampilkan; (4) sistematika penyusunan isi materi media animasi, ahli materi menjawab "b" cukup baik, sehingga skor yang diperoleh 3 dengan persentase sebesar $75 \%$. Berdasarkan kriteria interpretasi data $75 \%$ termasuk kualifikasi cukup valid, karena karena materi yang ditampilkan dalam media animasi tersusun secara sistematis; (5) kesesuaian materi yang disampaikan dengan tingkat kebutuhan atau perkembangan siswa, ahli materi menjawab "a" sesuai, sehingga skor yang diperoleh 4 dengan persentase sebesar $100 \%$.

Berdasarkan kriteria interpretasi data $100 \%$ termasuk kualifikasi valid, karena materi yang disajikan dalam media animasi ini sesuai dengan tingkat kebutuhan atau perkembangan siswa; (6) efisiensi waktu pemutaran media terhadap tujuan yang ditetapkan, ahli materi menjawab "b" cukup efisien, sehingga skor yang diperoleh 3 dengan persentase sebesar $75 \%$. Berdasarkan kriteria interpretasi data $75 \%$ termasuk kualifikasi cukup valid, karena waktu pemutaran atau durasi media animasi ini sudah cukup efisien terhadap tujuan yang telah ditetapkan; (7) kesesuaian antara bahasa yang digunakan dengan kemampuan siswa, ahli materi menjawab "a" cukup sesuai, sehingga skor yang diperoleh 3 dengan persentase sebesar $75 \%$.

Berdasarkan kriteria interpretasi data 75\% termasuk kualifikasi cukup valid, karena intonasi dan lafal narator dalam media animasi ini cukup jelas; (8) kejelasan intonasi dan lafal suara narator, ahli media menjawab "b" cukup jelas, sehingga skor yang diperoleh 3 dengan persentase sebesar $75 \%$. Berdasarkan kriteria interpretasi data $75 \%$ termasuk kualifikasi cukup valid, karena teks yang ditampilkan dalam media animasi ini sudah cukup jelas; (9) kesesuaian format media yang ditampilkan dengan topik yang disampaikan, ahli media menjawab "a" sesuai, sehingga skor yang diperoleh 4 dengan persentase sebesar 100\%.

Berdasarkan kriteria interpretasi data $100 \%$ termasuk kualifikasi valid, format yang digunakan dalam media animasi ini sesuai untuk menampilkan topik yang disajikan karena format yang digunakan dalam media animasi ini sesuai untuk menampilkan topik yang disajikan; dan (10) kesesuaian media untuk mencapai tujuan yang diharapkan, pengiring dan penutup, ahli media menjawab "b" sesuai, sehingga skor yang diperoleh 3 dengan persentase sebesar $75 \%$. Berdasarkan kriteria interpretasi data $75 \%$ termasuk kualifikasi valid, karena media yang digunakan sesuai untuk mencapai tujuan yang telah ditetapkan. Dari analisis hasil uji coba atau validasi tersebut, ahli materi memberikan beberapa saran terhadap media animasi yang sedang dikembangkan, yaitu perlu diberikan soal evaluasi.

Berdasarkan hasil olahan data ahli media, dari 10 item yang divalidasi, maka kriteria penilaian pada aspek media termasuk dalam kriteria valid, memperoleh skor 35 dengan persentase sebesar $87,5 \%$. Berdasarkan hasil validasi ahli media dapat dianalisis sebagai berikut, dalam hal: (1) kesesuaian materi untuk ditampilkan dalam bentuk animasi, ahli media menjawab "a" sesuai, sehingga skor yang diperoleh 4 dengan persentase sebesar $100 \%$. Berdasarkan kriteria interpretasi data $100 \%$ termasuk kualifikasi valid, karena media animasi yang sedang dikembangkan memiliki kesesuaian materi untuk ditampilkan dalam bentuk animasi; (2) kesesuaian media dengan Kompetensi Inti (KI) dan Kompetensi Dasar (KD), ahli media menjawab "a" sesuai, sehingga skor yang diperoleh 4 dengan 
persentase sebesar $100 \%$. Berdasarkan kriteria interpretasi data $100 \%$ termasuk kualifikasi valid, karena media animasi ini sesuai dengan KI dan KD; (3) kesesuaian narasi dengan gambar, ahli media menjawab "b" cukup sesuai, sehingga skor yang diperoleh 3 dengan persentase sebesar $75 \%$. Berdasarkan kriteria interpretasi data $75 \%$ termasuk kualifikasi cukup valid, karena narasi dalam media animasi cukup sesuai dengan gambar yang ditampilkan; (4) tampilan media animasi secara keseluruhan, ahli media menjawab "b" cukup baik, sehingga skor yang diperoleh 3 dengan persentase sebesar $75 \%$.

Berdasarkan kriteria interpretasi data 75\% termasuk kualifikasi cukup valid, karena tampilan media animasi secara keseluruhan sudah cukup baik untuk digunakan dalam pembelajaran; (5) kesesuaian komposisi yang ditampilkan dalam media animasi, ahli media menjawab "b" cukup sesuai, sehingga skor yang diperoleh 3 dengan persentase sebesar 75\%. Berdasarkan kriteria interpretasi data $75 \%$ termasuk kualifikasi cukup valid, karena komposisi yang ditampilkan dalam media animasi ini sudah cukup sesuai; (6) kejelasan animasi dan gambar, ahli media menjawab "b" cukup jelas, sehingga skor yang diperoleh 3 dengan persentase sebesar $75 \%$. Berdasarkan kriteria interpretasi data $75 \%$ termasuk kualifikasi cukup valid, karena animasi dan gambar yang ditampilkan dalam media animasi ini sudah cukup jelas; (7) kejelasan intonasi dan lafal narator, ahli media menjawab "b" cukup jelas, sehingga skor yang diperoleh 3 dengan persentase sebesar $75 \%$.

Berdasarkan kriteria interpretasi data $75 \%$ termasuk kualifikasi valid, karena intonasi dan lafal narator dalam media animasi ini cukup jelas; (8) kejelasan teks yang ditampilkan, ahli media menjawab "a" jelas, sehingga skor yang diperoleh 4 dengan persentase sebesar 100\%. Berdasarkan kriteria interpretasi data 100\% termasuk kualifikasi valid, karena teks yang ditampilkan dalam media animasi ini sudah jelas; (9) gangguan dari backsound yang digunakan, ahli media menjawab "b" sedikit mengganggu, sehingga skor yang diperoleh 3 dengan persentase $75 \%$. Berdasarkan kriteria interpretasi data $75 \%$ termasuk kualifikasi cukup valid, karena backsound yang digunakan dalam media animasi ini sedikit mengganggu; dan (10) kesesuaian antara musik pembuka, pengiring dan penutup, ahli media menjawab "a" cukup sesuai, sehingga skor yang diperoleh 34 dengan persentase sebesar $100 \%$.

Berdasarkan kriteria interpretasi data $100 \%$ termasuk kualifikasi cukup valid, karena musik pembuka, pengiring dan penutup yang ditampilkan dalam media animasi ini sudah cukup sesuai. Pada analisis hasil uji coba validasi di atas, ahli media memberikan beberapa saran terhadap media animasi yang sedang dikembangkan, yaitu kejelasan animasi gambar dan backsound yang digunakan dalam media animasi supaya diperbaiki. Dengan demikian dapat dikatakan bahwa hasil validasi dari ahli media, mengenai kualitas media pembelajaran berbasis multimedia pembelajaran pengukuran teknik ditinjau dari aspek media adalah baik. Meskipun demikian, media pembelajaran ini masih perlu penyempurnaan berdasarkan saran-saran perbaikan dari ahli media.

Uji coba satu-satu dilakukan dengan memberikan penilaian berdasarkan pada data instrumen yang diisi oleh tiga orang siswa. Berdasarkan pengolahan data di atas, diperoleh hasil 69\%. Berdasarkan hasil pengolahan data kriteria yang telah ditentukan, diketahui bahwa media animasi pengukuran teknik yang dikembangkan termasuk dalam kategori cukup valid dan dapat digunakan dalam proses pembelajaran ke tahap berikut. Berdasarkan hasil uji coba audience dapat dianalisis sebagai berikut: (1) memahami materi dalam media animasi, dua siswa menyatakan "b" cukup memahami, dan satu siswa menyatakan "c" kurang memahami, sehingga skor yang diperoleh 8 dengan persentase sebesar $66,6 \%$. Berdasarkan kriteria interpretasi data $66,6 \%$ termasuk kualifikasi valid; (2) mengerti bahasa yang digunakan, dua siswa menyatakan "b" cukup dimengerti, dan satu siswa menyatakan 
"c" kurang dimengerti, sehingga skor yang diperoleh 8 dengan persentase sebesar $66,6 \%$.

Berdasarkan kriteria interpretasi data $66,6 \%$ termasuk dalam kualifikasi cukup valid; (3) mendapatkan pengetahuan baru dari media animasi, satu siswa menyatakan "a" banyak mendapatkan pengetahuan baru, satu siswa menyatakan "b" cukup mendapat pengetahuan baru, dan satu siswa menyatakan "c" tidak mendapatkan pengetahuan baru, sehingga skor yang diperoleh 9 dengan persentase sebesar $75 \%$. Berdasarkan kriteria interpretasi data $75 \%$ termasuk kualifikasi cukup valid; (4) pengaruh musik pengiring terhadap penyampaian materi, satu siswa menyatakan "b" kurang mengganggu sedangkan dua siswa menyatakan "c" cukup mengganggu, sehingga skor yang diperoleh 7 dengan persentase sebesar 58,3\%.

Berdasarkan kriteria interpretasi data $58,31 \%$ termasuk dalam kualifikasi kurang valid; (5) kejelasan materi dalam media animasi, dua siswa menyatakan "b" cukup jelas satu siswa menyatakan "c" kurang jelas, sehingga skor yang diperoleh 8 dengan persentase sebesar $66,6 \%$. Berdasarkan kriteria interpretasi data $66,6 \%$ termasuk kualifikasi cukup valid; (6) tempo atau kecepatan penyajian materi, dua siswa menyatakan "b" agak cepat, satu siswa menyatakan "c" cepat, sehingga skor yang diperoleh 8 dengan persentase sebesar $66,6 \%$. Berdasarkan kriteria interpretasi data $66,6 \%$ termasuk kualifikasi cukup valid; (7) perasaan setelah belajar dengan media animasi, satu siswa menyatakan "a" senang, dua siswa menyatakan "b" cukup senang, sehingga skor yang diperoleh 9 dengan persentase sebesar $75 \%$.

Berdasarkan kriteria interpretasi data $75 \%$ termasuk kualifikasi cukup valid; (8) pengaruh media animasi terhadap kesenangan untuk belajar, satu siswa menyatakan "a" senang, satu siswa menyatakan "b" cukup senang, satu siswa menyatakan "d" tidak senang, sehingga skor yang diperoleh 9 dengan persentase sebesar $75 \%$. Berdasarkan kriteria interpretasi data $75 \%$ termasuk dalam kualifikasi cukup valid; dan
(9) Kemenarikan belajar menggunakan media animasi, satu siswa menyatakan "a" menarik, dua siswa menyatakan "b" cukup menarik, sehingga skor yang diperoleh 9 dengan persentase sebesar $75 \%$. Berdasarkan kriteria interpretasi data $75 \%$ termasuk kualifikasi cukup valid.

Pada analisis hasil uji coba atau validasi tersebut, audience memberikan beberapa saran terhadap media animasi yang sedang dikembangkan diantaranya musik pengiring terhadap kejelasan materi untuk di kecilkan volume suaranya. Uji coba kelompok kecil dilaksanakan setelah uji coba satu-satu. Berdasarkan analisis data uji coba satu-satu, multimedia yang dikembangkan oleh peneliti layak dilanjutkan untuk di uji pada kelompok kecil. Berdasarkan penilaian siswa, secara keseluruhan multimedia yang dikembangkan mengalami kenaikan persentase dari 69\% menjadi $77 \%$ walaupun masih dalam kriteria cukup valid.

Berdasarkan hasil uji coba kelompok kecil dapat dianalisis: (1) memahami materi dalam media animasi, lima siswa menyatakan "a" mudah memahami, tiga siswa menyatakan "b" cukup memahami, dan enam siswa menyatakan "c" kurang memahami, dan satu orang menyatakan "d" tidak memahami, sehingga skor yang diperoleh 42 dengan persentase sebesar $70 \%$. Berdasarkan kriteria interpretasi data $70 \%$ termasuk kualifikasi cukup valid; (2) mengerti bahasa yang digunakan, empat siswa menyatakan "a" mudah dimengerti, lima siswa menyatakan "b" cukup dimengerti, dan enam siswa menyatakan "c" kurang dimengerti, sehingga skor yang diperoleh 43 dengan persentase sebesar 71,6\%. Berdasarkan kriteria interpretasi data $71,6 \%$ termasuk dalam kualifikasi cukup valid; (3) mendapatkan pengetahuan baru dari media animasi, empat siswa menyatakan "a" banyak mendapatkan pengetahuan baru, delapan siswa menyatakan "b" cukup mendapat pengetahuan baru, dan tiga orang menyatakan "c" kurang mendapat pengetahuan, sehingga skor yang 
diperoleh adalah 47 dengan persentase sebesar $78,3 \%$. Berdasarkan kriteria interpretasi data $78,3 \%$ termasuk dalam kualifikasi cukup valid; (4) pengaruh musik pengiring terhadap penyampaian materi, tiga siswa menyatakan " $a$ " tidak mengganggu, tujuh siswa menyatakan " $b$ " sedikit mengganggu, lima siswa menyatakan "c" cukup mengganggu, sehingga skor yang diperoleh 43 dengan persentase sebesar $71,6 \%$. Berdasarkan kriteria interpretasi data 93,1\% termasuk kualifikasi cukup valid; (5) kejelasan materi dalam media animasi, lima siswa menyatakan "a" jelas, enam siswa menyatakan "b" cukup jelas, tiga siswa menyatakan "c" kurang jelas, dan satu siswa menyatakan "d" tidak jelas sehingga skor yang diperoleh 45 dengan persentase sebesar $75 \%$.

Berdasarkan kriteria interpretasi data $75 \%$ termasuk dalam kualifikasi cukup valid; (6) tempo atau kecepatan penyajian materi, empat siswa menyatakan "a" sedang, tujuh siswa menyatakan "b" agak cepat, empat siswa menyatakan "c" cepat, sehingga skor yang diperoleh 49 dengan persentase sebesar $81,6 \%$. Berdasarkan kriteria interpretasi data $81,6 \%$ termasuk kualifikasi valid; (7) perasaan setelah belajar dengan media animasi, enam siswa menyatakan "a" senang, tujuh siswa menyatakan "b" cukup senang, dua siswa menyatakan "c" kurang senang, sehingga diperoleh 49 dengan persentase sebesar $81,6 \%$.

Berdasarkan kriteria interpretasi data $81,6 \%$ termasuk kualifikasi valid; (8) pengaruh media animasi terhadap kesenangan untuk belajar, tujuh siswa menyatakan "a" senang, empat siswa menyatakan "b" cukup senang, tiga siswa menyatakan "c" kurang senang, dan satu siswa menyatakan "d" tidak senang, sehingga skor yang diperoleh 47 dengan persentase $78,3 \%$. Berdasarkan kriteria interpretasi data $78,3 \%$ termasuk dalam kualifikasi cukup valid; (9) kemenarikan belajar menggunakan media animasi, delapan siswa menyatakan "a" menarik, empat siswa menyatakan "b" cukup menarik, tiga siswa menyatakan "c" kurang menarik, sehingga skor yang diperoleh 51 dengan persentase sebesar $85 \%$. Berdasarkan kriteria interpretasi data $85 \%$ termasuk kualifikasi valid; dan (10) kejelasan suara narator, empat siswa menyatakan "a" jelas, delapan siswa menyatakan "b" cukup jelas, dan tiga siswa menyatakan kurang jelas, sehingga skor yang diperoleh 46 dengan persentase sebesar 76,6\%.

Berdasarkan kriteria interpretasi data $76,6 \%$ termasuk kualifikasi cukup valid. Dari analisis hasil uji coba kelompok kecil di atas sudah menunjukkan peningkatan skor. Dari hasil uji coba satu-satu, untuk mencapai kategori valid dan layak dilanjutkan pada uji coba kelompok besar. Data Rangkuman Hasil Belajar siswa dapat dilihat pada Tabel 1.

Tabel 1. Data Rangkuman Hasil Belajar

\begin{tabular}{ccccc}
\hline $\begin{array}{c}\text { Sumber } \\
\text { Statistik }\end{array}$ & $\mathrm{A}_{1}$ & $\mathrm{~A}_{2}$ & $\sum \mathrm{b}$ \\
\hline$\sum \mathrm{k}$ & $\mathrm{N}$ & 30 & 30 & 60 \\
& $\bar{X}$ & 78,83 & 69,78 & 74,31 \\
\hline
\end{tabular}

Keterangan:

$\mathrm{A}_{1}$ : Kelompok siswa yang diajar dengan metode pembelajaran multimedia

$\mathrm{A}_{2}$ : Kelompok siswa yang diajar dengan metode pembelajaran konvensional

$\bar{X}$ : Skor rerata hasil belajar

$\mathrm{n}$ : Banyaknya sampel

Hasil evaluasi diperoleh nilai rata-rata kelas eksperimen (kelas XIA) yaitu 78,83 dan nilai rata-rata kelas kontrol (kelas XIB) yaitu 69,78. Berdasarkan proses pembuatan media interaktif pengukuran teknik dapat diketahui bahwa proses pembuatan media tersebut dengan langkah antara lain melalui tiga tahap yaitu: (1) analisis kebutuhan; (2) pengembangan produk, yang meliputi desain indeks, navigasi dan konten; dan (3) uji coba satu-satu, uji coba kelompok kecil dan implementasi produk akhir. Berdasarkan analisis efektivitas kelompok kontrol dan eksperimen di atas dapat diketahui bahwa terdapat perbedaan antara siswa yang 
menggunakan multimedia pengukuran teknik dan siswa yang menggunakan pembelajaran konvensional.

Berdasarkan hasil analisis data tersebut dapat dilihat bahwa media pengukuran teknik lebih efektif daripada media konvensional. Ini dapat dilihat dari perbedaan antara kelas kontrol (konvensional) dengan nilai rata-rata 69,78 dan kelas eksperimen dengan nilai rata-rata 78,83 . Hasil tersebut dapat dilihat karena faktor pembelajaran yang dilakukan. Multimedia pengukuran teknik memberikan kontribusi yang lebih baik terhadap pemahaman siswa dalam pembelajaran. Beberapa kelebihan multimedia yang dikembangkan ini adalah dapat dijadikan salah satu alternatif sumber belajar mandiri untuk mengatasi kelemahan pembelajaran yang dilaksanakan secara klasikal. Penelitian ini menunjukkan bahwa penggunaan media pembelajaran berpengaruh positif terhadap hasil belajar siswa dan juga terdapat peningkatan prestasi belajar siswa setelah menggunakan media pembelajaran.

\section{SIMPULAN}

Berdasarkan hasil penelitian, dapat ditarik kesimpulan sebagai berikut: (1) proses pembuatan media pembelajaran pada penelitian ini dilakukan melalui tiga tahap yaitu: analisis kebutuhan, pengembangan produk meliputi desain indeks, navigasi dan konten, uji coba satu-satu, uji coba kelompok kecil dan implementasi produk akhir; dan (2) produk multimedia ini dapat digunakan sebagai salah satu media untuk meningkatkan pemahaman materi pengukuran teknik. Ada perbedaan hasil belajar siswa. Media interaktif pengukuran teknik lebih efektif dibandingkan media konvensional. Ini dapat dilihat dari perbedaan antara kelas kontrol (konvensional) dengan nilai rata-rata 69,78 dan kelas eksperimen dengan nilai rata-rata 78,83 .

\section{DAFTAR RUJUKAN}

Borg, W. R., and Gall, M. D. 1989. Educational Research: An introductioh n (5th ed.). New York, NY: Longman

Dick, Walker and Carey, Lou., James O. 2001. The Systematic Design of Instruction (5th ed). New York. Longman.

Finch C. 1999. Curricullum Development in Vocational and Technical Education. Boston: MA: Allyn and Bacon

Pavlova, M. 2009. Technology and Vocational Education for Sustainable Developmen, Empowering Individuals for the Future. Bonn; Springer

Prosser. Charles A. and T.H. Queqley. 1950. Vocational Education in Democracy. Chicago: American Technical Society 